\title{
VIABILITY OF THE USE OF MINIMUM WATER QUALITY INDICES: A COMPARISON OF METHODS
}

\author{
Amanda R. M. de Oliveira ${ }^{1}$, Alisson C. Borges ${ }^{2 *}$, Antonio T. Matos ${ }^{3}$, Moysés Nascimento ${ }^{1}$ \\ ${ }^{2 *}$ Corresponding author. Universidade Federal de Viçosa/ Viçosa - MG, Brasil. E-mail: borges@ufv.br
}

\section{KEYWORDS}

water quality index, Bascarán index, water quality monitoring parameters.

\begin{abstract}
The achievement of all the water quality parameters that constitute the water quality indices can be a hamper to their use. The objective of this study was to analyze the viability of using minimum indices to monitor water quality, comparing different methods. For this purpose, the Environmental Company of the State of São Paulo database for the year 2016 of the Tietê/Jacaré and the Tietê/Batalha units was used. Four indices present in the literature were compared with the indices currently practiced in the states of São Paulo and Minas Gerais ("standard indices"). For feasibility analysis, the indices were classified by the "standard indices" methods and compared to them. The minimum indices were significantly correlated with the "standard indices", from moderate to strong degree. The minimum indices, as a rule, overestimated water quality when compared to the index of the state of Minas Gerais; and underestimated when compared to the index of the state of São Paulo. It is concluded that the minimum indices are useful and practicable tools, with respect to the use of the WQI for management purposes. However, such indices should be evaluated periodically to avoid making mistaken decisions.
\end{abstract}

\section{INTRODUCTION}

Knowledge of water quality in streams and rivers is essential for the management of water resources. The water quality of any specific area or source can be assessed by means of physical, chemical and biological parameters (Tyagi et al., 2013).

Referring to water quality is not just about the quantification of physical and chemical parameters. The water quality is a reflection of the combined effect of several processes that occur in the water body, that is, the functioning of the ecosystem (Bueno et al., 2005). The Water Quality Indices (WQI) then came as integrators of the physical, chemical and biological characteristics of the waters, providing indications of the ecosystem dysfunctions and contributing to the most efficient decision-making in the management of watersheds, reflecting the level of water salubrity (Bertossi et al., 2013). Therefore, the WQIs have been widely used to identify spatial and temporal variation in water quality in a watershed (Coletti et al., 2010).

WQIs are simplistic mathematical instruments that transform complex water quality data into information that is understandable and usable by the public, indicating the level of quality of water resources (Sánchez et al., 2007; Jerônimo \& Souza, 2013; Srivastava \& Kumar, 2013).

In Brazil, the National Sanitation Foundation (NSF) index of the United States (WQI-NSF) is currently the basis of the indices practiced. This WQI was developed by Brown et al. (1970) and consists of a weighted average index of nine parameters of water quality, being: dissolved oxygen (DO), fecal coliforms (FC), biochemical oxygen demand (BOD), $\mathrm{pH}$, variation of temperature, phosphates, nitrates, turbidity and total solids (TS) (Brown et al., 1970). Some of these parameters need laboratory analysis, with results that require minimum time of at least 5 days.

Obtaining all water quality parameters that make up the index may not be an easy practice due to the demand for time or because of test failures (Srivastava \& Kumar, 2013), making the application of WQI unfeasible (Bertossi et al., 2013, CETESB, 2015). In addition, the large number of parameters to obtain generates expenses, besides the environmental cost resulting from the analytical products used in the analyzes.

In this context, the development of modified indices in order to obtain satisfactory results, using a reduced number of parameters, is extremely important for

${ }^{1}$ Universidade Federal de Viçosa/ Viçosa - MG, Brasil.

${ }^{3}$ Universidade Federal de Minas Gerais/ Belo Horizonte - MG, Brasil.

Received in: 1-19-2018

Accepted in: 6-5-2018 
cost reduction (Akkoyunlu \& Akiner, 2012). This fact is proven by the good number of literary material dealing with the elaboration of minimum indices to portray water quality in various parts of the world. As examples, one can list the study of Pesce \& Wunderlin (2000), in Argentina, who proposed a minimum WQI with 3 parameters; the Moscuzza et al. (2007), who also in Argentina proposed a minimum WQI with only 2 parameters; and the recent study by Naveedullah et al. (2016), who proposed a minimum index with 5 parameters in China.

Oliveira (2017), also presents water quality indices with reduced number of parameters (WQI ${ }_{\text {red }}$ ). These indices were developed for waters of the Doce river basin specifically the Piranga and Piracicaba River - and equivalent to the index currently practiced in the state of Minas Gerais ( $\mathrm{WQI}_{\mathrm{IGAM}}$ ). The main proposal contemplated 6 parameters and, the alternative proposal, 5 parameters.

Knowing the importance of this subject, this research aimed to analyze the feasibility of using minimum indices to monitor water quality, comparing different methods, applied to the quality database of inland waters of the Tietê river basin.

\section{MATERIAL AND METHODS}

\section{Study area}

To evaluate the feasibility of the indices presented in the literature, the Tietê river basin was chosen, specifically the Water Resources Management Units (UGRHIs) from Tietê/Jacaré and Tietê/Batalha.

The basin area of the Tietê River is in the Southeast region, integrating the Paraná River basin, with a drainage area of approximately $73,400 \mathrm{~km}^{2}$, and a population of approximately 29.2 million inhabitants. The Tietê River is the longest river in the state of São Paulo - going through São Paulo State's lands only, in the east-west direction, in an extension of approximately $1,100 \mathrm{~km}$ - born on the cliffs of Serra do Mar, $22 \mathrm{~km}$ from the coast, in the municipality of Salesópolis and its mouth is located in the Paraná river, in the border with the State of Mato Grosso do Sul, in the municipality of Itapurá (São Paulo, 2011).

This basin includes six UGRHIs, being: Piracicaba/Capivari/Jundiaí (UGRHI 05); Alto Tietê (UGRHI 06); Tietê/Sorocaba (UGRHI 10); Tietê/Jacaré (UGRHI 13); Tietê/Batalha (UGRHI 16); and Low Tietê (UGRHI 19) (São Paulo, 2013).

The choice of the Tietê river basin and the two UGRHIs, Jacaré and Batalha, was based on the fact that it is of great socioeconomic and political importance, since it is a basin with intense economic activity and population occupation, like the two basin units of the Doce River, studied by Oliveira (2017).

\section{Characteristics of the data}

In order to analyze the feasibility of the use of minimum indices in the monitoring of water quality, comparing different methods, a survey was made of the inland water quality database of the state of São Paulo. This information is provided by the Environmental Company of the State of São Paulo (CETESB), which monitors the quality of the inland waters of the state of São Paulo since 1974. For the present study, the monitoring of the last year was considered - in the case, year 2016, contemplating the necessary parameters for the calculation of the indices under analysis.

At present, CETESB has in its network of qualitative monitoring 449 points of sampling distributed by the main rivers and reservoirs (CETESB, 2017); 13 of which are located at UGRHI do Tietê/Jacaré and 9 at UGRHI Tietê/Batalha. The frequency of the analyzes is, as a rule, bimonthly.

\section{Pre-processing of data}

To avoid any problems that the presence of censored and lost values may cause in statistical analyzes, the database should be treated. To treat the censored values, usually present in environmental data, the methodology presented by Sabino et al. (2014) was used. The authors present that the values that are below the minimum limit of detection are replaced by half of the minimum limit of detection; however, the values that are above the maximum value measured by the responsible organ are maintained.

For missing data, the sampling point that did not have one of the necessary parameters to calculate the analyzed indices or did not present any of the parameters was excluded. Despite the small number of points sampled, it is a very complete database, with no missing parameters in the chosen period of the two UGRHIs under study.

\section{Minimum indices}

The study of the feasibility of the use of minimum indices in water quality monitoring included the index proposed by Pesce \& Wunderlin (2000), which consists of a minimum WQI with 3 parameters (DO, electrical conductivity (EC) and turbidity); the index proposed by Moscuzza et al. (2007), which consists of a minimum WQI with only 2 parameters (DO and EC); and the index proposed by Naveedullah et al. (2016), which consists of a minimum index with 5 parameters (DO, EC, turbidity, temperature and $\mathrm{pH}$ ). These three indices are based on the proposal of the Bascarán index (see Pesce \& Wunderlin (2000)) (Equation 1).

$$
\mathrm{WQI}_{\text {Bascarán }}=\mathrm{k} \frac{\sum_{\mathrm{i}=1}^{\mathrm{n}} \mathrm{C}_{\mathrm{i}} \mathrm{W}_{\mathrm{i}}}{\sum_{\mathrm{i}=1}^{\mathrm{n}} \mathrm{W}_{\mathrm{i}}}
$$

Where,

$\mathrm{k}$ - is a constant of adjustment according to the visual aspect of the waters, attributed according to the following scale: 1.00 for waters without apparent contamination; 0.75 for slightly contaminated waters; 0.50 for contaminated water; 0.25 for highly contaminated waters;

$\mathrm{Ci}$ - value assigned to each parameter, after normalization, and

$\mathrm{Wi}$ - relative weight assigned to each parameter, the value can vary from 1 to 4 , the value 4 being assigned to parameters that are most important for the preservation of aquatic life, and the value of 1 to parameters that has a smaller impact. 
The index proposed by Oliveira (2017) was also used for this comparison. It is a water quality index with a reduced number of parameters $\left(\mathrm{WQI}_{\mathrm{red}}\right)$ equivalent to the index currently practiced by the Minas Gerais Institute for Water Management (IGAM), in the state of Minas Gerais (WQI $I_{\text {IGAM }}$ ), developed for waters of the river basin Doce specifically the units of the Piranga River and the Piracicaba River - based on WQI IGAM (Equation 2).

$$
\mathrm{WQI}_{\text {IGAM }}=\prod_{\mathrm{i}=1}^{\mathrm{n}} \mathrm{q}_{\mathrm{i}}{ }^{\mathrm{w}_{\mathrm{i}}}
$$

Where,

$$
\text { WQI IGAM - Water Quality Index, ranging from } 0 \text { to }
$$
100

$\mathrm{q}_{\mathrm{i}}$ - quality of the parameter $\mathrm{i}$ obtained through the average specific quality curve;

$\mathrm{w}_{\mathrm{i}}$ - weight assigned to the parameter, according to its importance in quality, between 0 and 1 ,

$\mathrm{n}$ - number of parameters.

The WQI $\mathrm{Wed}_{\text {red }}$ is calculated using 5 parameters: (DO, $\mathrm{pH}$, temperature variation, nitrates and turbidity). Since the CETESB does not use nitrates to calculate WQI (using total nitrogen), it was also chosen to analyze this $\mathrm{WQI}_{\text {red }}$ in the absence of nitrate parameters. Thus, for the comparison, $\mathrm{WQI}_{\text {red }}{ }^{\mathrm{IGAM}}$ (DO, $\mathrm{pH}$, temperature variation, nitrates and turbidity) and $\mathrm{WQI}_{\mathrm{red}}{ }^{\text {CETESB }}$ (DO, $\mathrm{pH}$, temperature variation and turbidity) were used.

Both indices use the same method of calculating the WQI practiced by IGAM and CETESB, but with a difference in the weight attributed to turbidity parameter due to its importance in quality. For the $\mathrm{WQI}_{\text {red }}{ }^{\mathrm{IGAM}}$, the parameter turbidity acquires the weight equal to 0.51 ; already for the $\mathrm{WQI}_{\text {red }}$ CETESB the weight is of 0.61. The other parameters have the same weight as the IGAM and CETESB method.

\section{Feasibility analysis}

In order to analyze the feasibility of using minimum indices to monitor water quality, the five indices described in the previous item were calculated and evaluated in relation to the indices currently practiced by IGAM and CETESB, WQI ${ }_{\text {IGAM }}$ and $\mathrm{WQI}_{\text {CETESB }}$, respectively. These two indices were chosen as "standard indices" because WQI ${ }_{\text {red }}$ was developed for a mining basin and applied in data of a São Paulo basin.

The calculation of WQI CETESB $_{\text {uses the same }}$ WQI IGAM method, however, with two differences: i) for the calculation of the index is considered the total nitrogen and not the nitrate form; ii) for the classification of water quality, different bands are used. For a more extensive analysis, the minimum indices were classified using the two bands (Table 1) and then compared to the two "standard indices", since Pesce \& Wunderlin (2000) and Moscuzza et al. (2007) do not present a specific classification for the proposed methods. In turn, Naveedullah et al. (2016) used an identical band of the IGAM (Table 1), possibly because this is the basis of WQI-NSF, since this index is internationally known (Jerônimo \& Souza, 2013) and the most widespread index (Menezes et al., 2013).

The WQI ${ }_{\text {red }}$ IGAM was classified using the IGAM band; already the WQI red $^{\text {CETESB }}$ using the band of CETESB. Both indices were also classified by applying the bands developed by Oliveira (2017) (BAND I and BAND II), to verify their reproducibility/flexibility.

TABLE 1. Classification of water quality according to IGAM and CETESB.

\begin{tabular}{cccc}
\hline & $W_{\text {CETESB }}$ & WQI IGAM & Band of WQI IGAM \\
\hline Level & Band of WQI & Level & $90<\mathrm{WQI} \leq 100$ \\
Great & $79<\mathrm{WQI} \leq 100$ & Excellent & $70<\mathrm{WQI} \leq 90$ \\
Good & $51<\mathrm{WQI} \leq 79$ & Good & $50<\mathrm{WQI} \leq 70$ \\
Regular & $36<\mathrm{WQI} \leq 51$ & Medium & $25<\mathrm{WQI} \leq 50$ \\
Bad & $19<\mathrm{WQI} \leq 36$ & Bad & $\mathrm{WQI} \leq 25$ \\
Terrible & $\mathrm{WQI} \leq 19$ & Very Bad & \\
\hline
\end{tabular}

Adapted from (CETESB, 2015; IGAM, 2016)

The indices were evaluated according to the Pearson correlation coefficient (r) and adequacy to the water quality classes in relation to the "standard indices".

\section{RESULTS AND DISCUSSION}

\section{Water quality of the Tietê river basin}

A preliminary analysis of the water quality of the Tietê/Batalha and Tietê/Jacaré UGRHIs for the year 2016 was carried out. Figure 1 shows the percentage of points within each class of $\mathrm{WQI}_{\mathrm{CETESB}}$, considering the complete data series and considering each monitored quarter. It was observed that, in general, the waters presented good quality in the year under study - approximately $84 \%$ of the points presented a rating between "Great" and "Good", $15 \%$ "Regular" and only $1 \%$ between "Bad" and
"Terrible". The analysis of each two months shows that this same profile is maintained.

The water quality was compromised, most of the time, due to $E$. coli parameters and turbidity. The quality score of these parameters, obtained through the average specific quality curve, on average, was 32 and 55, respectively.

The E. coli is an indicator of exclusively fecal contamination (von Sperling, 2014); and the turbidity may be associated with bacterial contamination (Pesce \& Wunderlin, 2000; Bakan et al., 2010), which may be of fecal origin. Since the WQI is sensitive to sewage contamination (IGAM, 2016), it is inferred that the low quality values of the E. coli parameters and turbidity are a signal of contamination of the watercourses by the discharge of sewage treated improperly or not treated. 


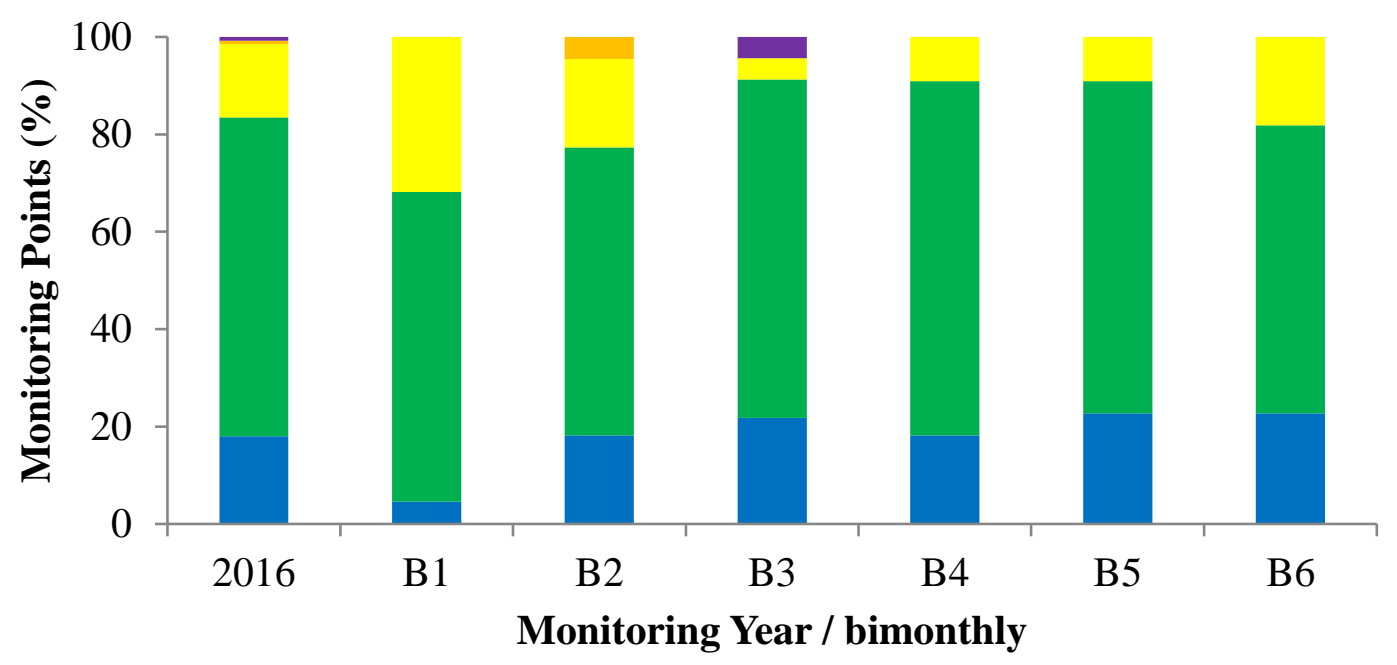

$\square$ GREAT GOOD REGULAR BAD $\square$ TERRIBLE

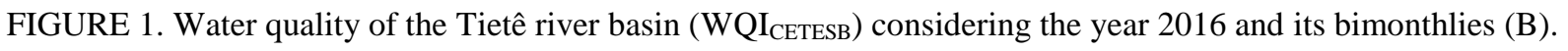

Water bodies that cross densely populated urban areas present an evident impairment of water quality due to the contribution of treated effluents or in natura sanitary sewers (ANA, 2013). This fits perfectly in the case of the Tietê River, which crosses one of the largest metropolises in Latin America. The CPRH (2015) confirms that the rivers of the state of São Paulo are compromised by sanitary sewers.

With the above, it is understood that the discharge of in natura sewage into the rivers has been one of the main responsible for the compromise of the water quality of the Tietê river basin. Pesce \& Wunderlin (2000), in Argentina; Kannel et al. (2007) in Nepal; Sánchez et al. (2007), in Spain; and Bakan et al. (2010) in Turkey also noted declining water quality in urban areas. This shows that the introduction of sanitary sewers into waterways is a problem that can be considered global.

Knowing the commitment of the water quality of the rivers of the state of São Paulo by sanitary sewers, CETESB uses total nitrogen to calculate WQI instead of nitrate (Lopes, 2007; von Sperling, 2007; CPRH, 2015). Sanitary sewage is rich in other forms of nitrogen, such as organic nitrogen and ammonia, thus justifying the fact that CETESB uses total nitrogen.

It was presented that one of the differences between

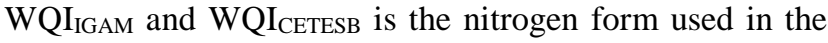
calculation, so, knowing the impact of sanitary sewage on river quality, Figure 2 presents a comparison between the IGAM and CETESB methods to verify the effect of the nitrogen form used in the indices.

Comparing the first two columns of the graph presented in Figure 2, there is a great difference between the methods, the one currently applied by the IGAM is much more restrictive, since little more than $40 \%$ of the points presented a classification between "Excellent" and "Good", compared to $84 \%$ of the points between "Great" and "Good", according to CETESB classification. However, when comparing values, it is verified that the $\mathrm{WQI}_{\text {CETESB }}$ and $\mathrm{WQI}_{\mathrm{IGAM}}$ present a significant positive correlation ( $\mathrm{p}$-value $<0.001$ ) of $\mathrm{r}=0.99$.

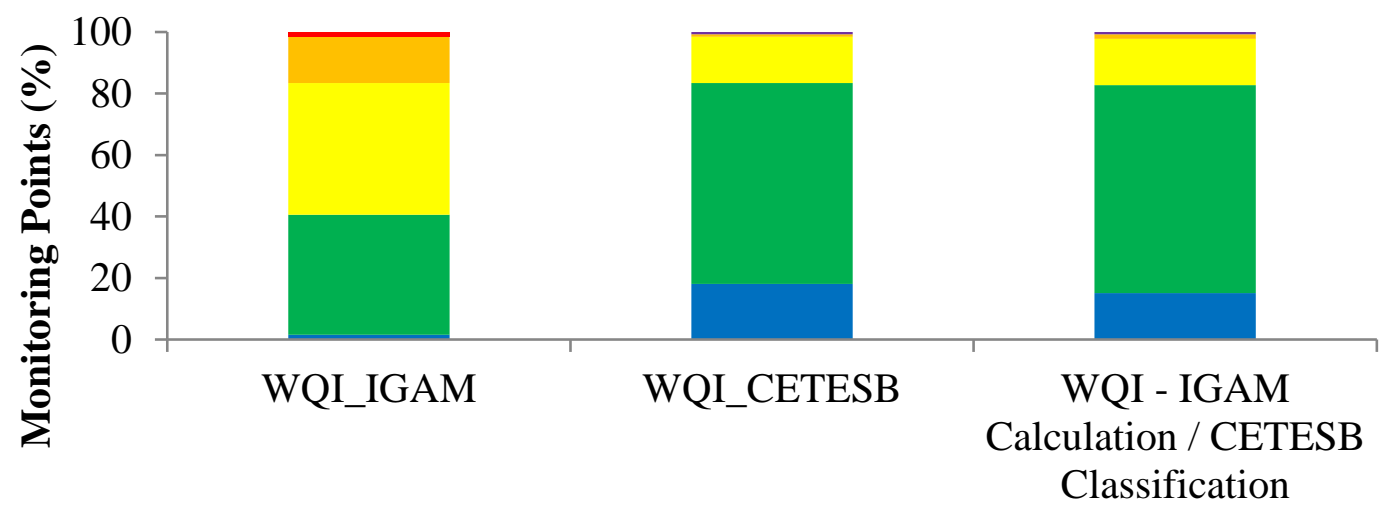

Indices

$\begin{array}{lll}\square \text { GREAT/EXCELLENT } & \text { GOOD } & \text { REGULAR/MEDIUM } \\ \square \text { BAD } & \square \text { TERRIBLE } & \text { VERY BAD }\end{array}$

FIGURE 2. Quality of water of the Tietê river basin - $\mathrm{WQI}_{\text {CETESB }}$ and WQI $\mathrm{IGAM}_{\text {. }}$ 
As the values are very similar, it is noted that it is not the total nitrogen or nitrate difference that is responsible for the discrepant classifications. The nonagreement of the bands was due to the values practiced by band to quality classification, more restrictive in the case of IGAM.

For a more reliable comparison, the third column of the graph shown in Figure 2 shows the percentage of

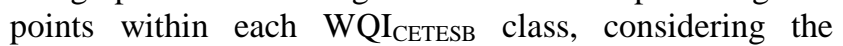
WQI IGAm calculation. Comparing the last two columns of Figure 2, it is noted that there is no difference between the calculation methods (considering total nitrogen or nitrate). Therefore, there are three hypotheses to justify the occurrence: i) it does not make any difference to the monitored nitrogen form - total nitrogen or nitrate - when the purpose is to calculate the WQI; ii) the fact that IGAM considers "full" nitrate $\left(\mathrm{mg} \mathrm{L}^{-1} \mathrm{NO}_{3}\right)$ (Ferreira \& Almeida, 2005) and not the nitrogen that is in the form of nitrate (mg L ${ }^{-1} \mathrm{~N}_{-\mathrm{NO}_{3}}$ )- as well as the WQI-NSF, which is the basis of both the WQI $\mathrm{WGAM}_{\mathrm{IGA}}$ and the $\mathrm{WQI}_{\text {CETESB }}$; iii) the predominant nitrogenous form in these water bodies is nitrate.
Considering that, in terms of calculating the WQI, the only difference between the IGAM and the CETESB method is the nitrogen related parameter, and analyzing the last two columns of Figure 2, it can be said that the second hypothesis is probably the more correct, at least in numerical terms. A small underestimation is noted when considering the IGAM calculation method; the only way to do this is to have the nitrate concentration higher than the total nitrogen concentration. As the total nitrogen contemplates all the nitrogenous forms present in the water (nitrite, nitrate, organic and ammoniacal nitrogen), the described fact can only occur if considered the "full" nitrate $\left(\mathrm{mg} \mathrm{L}^{-1} \mathrm{NO}_{3}\right)$ is considered.

\section{Feasibility analysis of using minimum water quality indices}

Table 2 presents the Pearson correlation coefficient of the minimum indices with $\mathrm{WQI}_{\mathrm{IGAM}_{\mathrm{G}} \text { and } \mathrm{WQI}} \mathrm{IETESB}_{\mathrm{C}}$, as well as the percentage of points that presented compatibility and incompatibility of classes with each of the "standard indices".

TABLE 2. Pearson correlation of the minimum indices with $\mathrm{WQI}_{\mathrm{IGAM}}$ and $\mathrm{WQI}_{\mathrm{CETESB}}$ and percentage with class compatibility and incompatibility.

\begin{tabular}{|c|c|c|c|c|c|}
\hline $\begin{array}{l}\text { Indices for } \\
\text { comparison }\end{array}$ & Minimum indices & $\mathrm{r}$ & Classes held (\%) & Overestimated (\%) & Underestimated (\%) \\
\hline \multirow{4}{*}{$\mathrm{WQI}_{\mathrm{CETESB}}$} & WQIred ${ }^{\text {CETESB }}$ & $0.78^{*}$ & 29 & 1 & 70 \\
\hline & Pesce \& Wunderlin (2000) & $0.74 *$ & 52 & 17 & 31 \\
\hline & Moscuzza et al. (2007) & $0.54 *$ & 32 & 1 & 67 \\
\hline & Naveedullah et al. (2016) & $0.69^{*}$ & 52 & 17 & 31 \\
\hline \multirow{4}{*}{$\mathrm{WQI}_{\text {IGAM }}$} & WQIred $^{\text {IGAM }}$ & $0.78 *$ & 60 & 22 & 18 \\
\hline & Pesce \& Wunderlin (2000) & $0.75^{*}$ & 37 & 56 & 7 \\
\hline & Moscuzza et al. (2007) & $0.55^{*}$ & 45 & 20 & 35 \\
\hline & Naveedullah et al. (2016) & $0.71 *$ & 41 & 56 & 3 \\
\hline
\end{tabular}

*: significant correlation at the 0.001 level of probability by the $t$ test.

Dancey \& Reidy (2008) classify the correlations by the magnitude of the Pearson correlation coefficient, where $0.10 \leq|\mathrm{r}|<0.40$, indicates a weak correlation; 0,40 $\leq|\mathrm{r}|<0.70$, moderate correlation; $0,70 \leq|\mathrm{r}|<1$, strong correlation; and, $|\mathrm{r}|=1$, perfect correlation. Therefore, the $\mathrm{WQI}_{\mathrm{red}}{ }^{\text {CETESB }}$ and Pesce \& Wunderlin (2000) indices are strongly correlated with the WQI $\mathrm{WETESB}_{\text {; }}$ however, the Moscuzza et al. (2007) and Naveedullah et al. (2016) indices presented a moderate correlation with the WQI $I_{\text {CETESB }}$, all of these correlations being positive and significant. For the $\mathrm{WQI}_{\mathrm{IGAM}}$, with the exception of the Moscuzza et al. (2007), which presented moderate correlation with $\mathrm{WQI}_{\mathrm{IGAM}}$, the other indices are strongly correlated with this index; all, also, positive and significant.

It would expect that the index of Naveedullah et al. (2016) presented a better correlation with the "standard indices", compared to the Pesce \& Wunderlin (2000) index, since it presents a greater number of parameters coincident with $\mathrm{WQI}_{\mathrm{IGAM}}$ and $\mathrm{WQI}_{\mathrm{CETESB}}$. While, the $\mathrm{pH}$ parameter slightly interferes with the water quality variability, since, within the database analyzed, it is the parameter that presents the highest quality average, with one of the smallest standard deviations, that is, little variation. In addition, the "standard indices" include the temperature variation parameter, the quality being constant and equal to 93. While the Naveedullah et al. (2016) index considers the parameter temperature, being the quality, not constant, with average 79 and one of the largest standard deviation.

The reduced indices - WQI ${ }_{\text {red }}{ }^{\text {IGAM }}$ and WQI ${ }_{\text {red }}{ }^{\text {CETESB }}$ - showed a better correlation with the "standard indices". This fact was already expected, since they were elaborated based on the same WQI IGAM method, which, in turn,

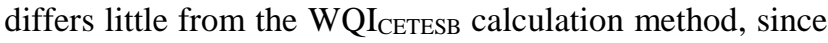
both have the same base (WQI-NSF). The other three indices are based on the proposal of the Bascarán index, a different method.

Considering this fact, it can be said that the methods proposed by Pesce \& Wunderlin (2000) and Naveedullah et al. (2016) generated quite satisfactory results, probably considering important parameters for the 
water quality of the studied region. The method presented by Moscuzza et al. (2007) did not present good results in relation to the "standard indices", certainly because it contemplates a very small number of parameters (DO and EC) that were not able to represent water quality more broadly.

It is important to note that the cost of the analytical process involved can be a limiting factor for water quality assessment (Kannel et al., 2007; Bakan et al., 2010), minimum and reduced indices, if considered for resource management purposes are useful and economically viable tools. These indices, being well correlated with the "standard indices", can be good indicators of the water quality profile. Thus, if some water quality inconsistency is observed, using the minimum or reduced indices, more precise analyzes could be performed so that management plans could be elaborated.

By opting for the use of indices with a reduced/minimum number of parameters, the management bodies should be aware of inconsistencies - regions with high effluent discharges present great/good water quality, for example. If any inconsistencies are observed, the reduced/minimum indices should be re-evaluated. Therefore, it is essential to maintain periodic monitoring routinely.

Another advantage of using the minimum and reduced indices presented in this study is the easiness in which all the parameters contemplated in these indices can be obtained; as they can be monitored using multiparameter water quality probes. Several types of such equipment are accredited and widely used throughout the world, in addition to having affordable prices (Akkoyunlu \& Akiner, 2012).

The use of multi-parameter probes can reduce the amount of data lost, since sampling, packaging and transport are not required - practices that could lead to loss of samples. Another interesting factor is the reduction in labor costs, chemical reagents and laboratory infrastructure. Also, the environmental cost of the analytical products used in the analyzes can be minimized. The use of these types of equipment to monitor water quality also enables real-time availability of data on websites and mobile apps; even thinking about the possibility of a WQI in real time.

Analyzing the percentage of points in conformity and disconformity of classes, it is observed that the minimum and reduced indices, as a rule, underestimated the water quality of the Tietê river basin, when classified

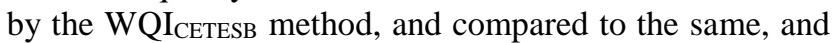
the methods proposed by Pesce \& Wunderlin (2000) and Naveedullah et al. (2016), despite the lowest correlation with WQI $\mathrm{CETESB}_{\mathrm{B}}$, presented the best class equivalence.

It is inferred that, under the conditions used in this research, the indices proposed by Pesce \& Wunderlin (2000) and Naveedullah et al. (2016) presented as good alternatives. Considering the practicity of the method, it is inferred that the method of Pesce \& Wunderlin (2000) presented the best performance, since this method contemplates a smaller number of quality parameters than the one proposed by Naveedullah et al. (2016) and, even so, presented the same percentages of class compatibility and incompatibility. The indices, in this situation, had the same perception of the water quality of the Tietê river basin, but the Pesce \& Wunderlin (2000) index required, for this, a smaller number of monitored parameters (DO, EC and turbidity).

When the minimum and reduced indices were classified by the WQI IGAM method and compared to the same, it was almost always observed that the water quality of the basin under study was overestimated. This overestimation of water quality was also reported by Pesce \& Wunderlin (2000), Moscuzza et al. (2007), Naveedullah et al. (2016); corroborating with the results obtained in this research.

Moscuzza et al. (2007) and Naveedullah et al. (2016) obtained better correlations between the reference index and the minimum index. This fact may have occurred because of the difference in the "standard" WQI. In this research, the WQI currently practiced by IGAM and CETESB was used, which originated from the WQI proposed by Brown et al. (1970). The above mentioned authors have used as reference the Bascarán index for the development of the proposal and also for the comparison. The way each one is calculated, the selected parameters may have favored obtaining better correlations.

The $\mathrm{WQI}_{\text {red }}{ }^{\mathrm{IGAM}}$, in addition to presenting a higher Pearson coefficient of correlation, presented the best equivalence of classes. Therefore, for a basin located in the state of Minas Gerais, the most viable index would be the $\mathrm{WQI}_{\text {red }}{ }^{\mathrm{IGAM}}$.

The use of minimum and reduced indices provided satisfactory results for the analysis of the water quality profile for the Tietê river basin. Monitoring by means of such indices would allow obtaining a monitoring map of water quality at a frequency lower than those currently used. In addition, the minimum and reduced indices presented and evaluated in this research have the potential to enable a monitoring system in real time, since all the considered parameters can be obtained directly using multi-parameter probes, and that the monitored data can be easily stored in data loggers and transmitted via satellite, radio, among others.

However, to obtain more reliable results using such indices, their values must be well correlated with the index currently practiced, in this case $\mathrm{WQI}_{\text {IGAM }}$ or WQI $\mathrm{WETESB}_{\text {. It }}$ would then only be necessary to maintain routine periodic monitoring using the "standard index" only to ensure the results obtained by prior monitoring of the minimum indices.

In Tables 3 and 4, for $\mathrm{WQI}_{\text {red }}{ }^{\text {IGAM }}$ and $\mathrm{WQI}_{\text {red }}{ }^{\text {CETESB }}$, the percentage of points with compatibility and

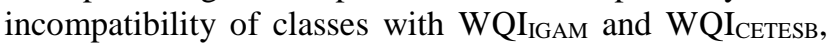
respectively, were obtained, and these two new indices were classified by the bands developed by Oliveira (2017).

Comparing the values presented in Table 2 with Table 3, it is verified that little compatibility of classes of the reduced index when classified in the new bands and compared to the $\mathrm{WQI}_{\mathrm{IGAm}}$ changed a little. 
TABLE 3. Percentage of points with class compatibility and incompatibility with $\mathrm{WQI}_{\mathrm{IGAM}}$ - for $\mathrm{WQI}_{\mathrm{red}}{ }^{\mathrm{IGAM}}$, classified by the two new quality bands.

\begin{tabular}{ccc}
\hline & & $\mathrm{WQI}_{\mathrm{red}}^{\mathrm{IGAM}}(\%)$ \\
\hline \multirow{2}{*}{ BAND I } & Classes held & 66 \\
& Overestimated & 15 \\
& Underestimated & 19 \\
\hline \multirow{3}{*}{ BAND II } & Classes held & 59 \\
& Overestimated & 12 \\
& Underestimated & 29 \\
\hline
\end{tabular}

The new bands were developed in order to provide better equivalence between the reduced index and the WQI IGAM - as $_{\text {I }}$ verified and confirmed in the previous chapter. By applying them to WQI $\mathrm{I}_{\text {red }}$ results from a database other than the one used to compile such bands, you can check whether they are reproducible/flexible. Therefore, given the unsatisfactory results, it is inferred that the new band are specific to the conditions in which they were developed.

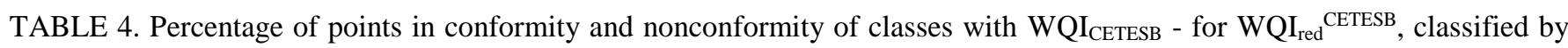
the two new quality bands.

\begin{tabular}{|c|c|c|}
\hline & & $\mathrm{WQI}_{\text {red }}{ }^{\text {CETESB }}(\%)$ \\
\hline \multirow{3}{*}{ BAND I } & Classes held & 17 \\
\hline & Overestimated & 1 \\
\hline & Underestimated & 82 \\
\hline \multirow{3}{*}{ BAND II } & Classes held & 11 \\
\hline & Overestimated & 2 \\
\hline & Underestimated & 87 \\
\hline
\end{tabular}

It can be observed, comparing the data presented in Table 2 with Table 4, which the percentage of points with class compatibility reduced and the underestimation of water quality increased significantly. As already presented, the new tracks were developed in order to provide better equivalence between $\mathrm{WQI}_{\mathrm{red}}$ and $\mathrm{WQI}_{\mathrm{IGAM}}$; being the classification band of $\mathrm{WQI}_{\mathrm{CETESB}}$ much less restrictive than that of $\mathrm{WQI}_{\mathrm{IGAM}}$, the underestimation of water quality in this situation was already expected. For better results, new bands should be developed in order to provide better equivalence between the two new indices and the WQI $_{\text {CETESB. }}$

\section{CONCLUSIONS}

The minimum indices are useful and practicable tools for the use of WQI for management purposes, although it tends to underestimate, when compared to $\mathrm{WQI}_{\text {CETESB }}$, and overestimate when compared to WQI IGAM.

The reduced index methods, developed based on

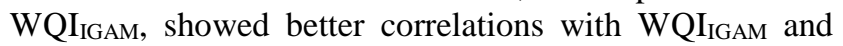

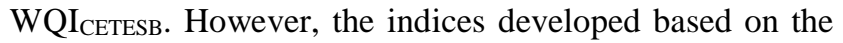
Bascarán index presented better equivalence of classes, when classified by the WQI $\mathrm{IETESB}_{\text {method and compared }}$ to the same. On the other hand, the reduced index presented better equivalence of classes when classified by the WQI $\mathrm{IGAM}_{\mathrm{I}}$ method and compared to the same.

The use of new classification bands in water quality for reduced rates implies poor reproducible/flexible methods and it is possible to apply only to the place where they were developed.

To obtain more reliable results using the minimum indices, their values must be well correlated with the index currently practiced, and it is necessary to maintain routine periodic monitoring to evaluate the minimum indices, avoiding mistaken decisions.

Minimum and reduced indices are useful and practicable tools regarding the use of WQI for management purposes. In addition, a monitoring system can be seen in real time, with the use of telemetry and website hosting without great additional costs.

\section{ACKNOWLEDGMENTS} CETESB.

The authors would like to thank CNPq, IGAM and

This paper is dedicated to the memory of our wonderful colleague, Prof. Sílvio Bueno Pereira, who recently passed away.

\section{REFERENCES}

Akkoyunlu A, Akiner ME (2012) Pollution evaluation in streams using water quality indices: A case study from Turkey's Sapanca Lake Basin. Ecological Indicators 18:501-511.

ANA - Agência Nacional de Águas (2013) Conjuntura dos recursos hídricos no Brasil. ANA, 432p.

Bakan G, Özkoç HB, Tülek S, Cüce H (2010) Integrated environmental quality assessment of the Kiz1lirmak River and its coastal environment. Turkish Journal of Fisheries and Aquatic Sciences 10(4):453-462.

Bertossi APA, Cecílio RA, Neves MA, Garcia GO (2013) Qualidade da água em microbacias hidrográficas com diferentes coberturas do solo no sul do Espírito Santo. Revista Árvore 37(1):107-117. 
Brown RM, McClelland NI, Deininger RA, Tozer RG (1970) A water quality index - Do we dare? Water \& Sewage Works 117(10):339-343.

Bueno LF, Galbiatti JA, Borges MJ (2005) Monitoramento de variáveis de qualidade da água do Horto Ouro VerdeConchal-SP. Engenharia Agrícola 25(3):742-748.

CETESB - Companhia Ambiental do Estado de São Paulo (2015) In: WQI - Índice de Qualidade das Águas.

Available in: http://aguasinteriores.cetesb.sp.gov.br/wpcontent/uploads/sites/12/2013/11/02.pdf. Accessed: Aug 25, 2015.

CETESB - Companhia Ambiental do Estado de São Paulo (2017) Qualidade das águas interiores no estado de São Paulo 2016. CETESB. 282p.

Coletti C, Testezlaf R, Ribeiro TA, Souza RT, Pereira DA (2010) Water quality index using multivariate factorial analysis. Revista Brasileira de Engenharia Agrícola e Ambiental 14(5):517-522.

CPRH - Agência Estadual de Meio Ambiente (2015) Seleção de índices e indicadores de qualidade da água. Available in:

http://www.cprh.pe.gov.br/downloads/pnma2/qualidadeagua/selecaoIndiceIndicadores.pdf. Accessed: Jul 26, 2015.

Dancey CP, Reidy J (2008) Estatística sem matemática para psicologia. Porto Alegre, Artmed, 3 ed. 608p.

Ferreira ECF, Almeida MC (2005) Sistema de cálculo da qualidade da água (SCQA) Estabelecimento das Equações do índice de Qualidade das Águas (IQA) Programa Nacional do Meio Ambiente-PNMA II.

IGAM - Instituto Mineiro de Gestão das Águas (2016) Qualidade das águas superficiais de Minas Gerais em 2015 - Resumo executivo. IGAM, 179p.

Jerônimo CEM, Souza FRS (2013) Determinação do índice de qualidade da água da lagoa de Extremoz-RN: Série temporal e correlação a índices pluviométricos.

Revista Eletrônica em Gestão, Educação e Tecnologia Ambiental 10(10):2219-2232. DOI: https://dx.doi.org/10.5902/223611707888

Kannel PR, Lee S, Lee YS, Kanel SR, Khan SP (2007) Application of Water Quality Indices and Dissolved Oxygen as Indicators for River Water Classification and Urban Impact Assessment. Environmental Monitoring and Assessment 132(1): 93-110. DOI:

https://dx.doi.org/10.1007/s10661-006-9505-1

Lopes FWA (2007) Avaliação da qualidade das águas e condições de balneabilidade na bacia do Ribeirão de Carrancas-MG. Dissertação Mestrado, Universidade Federal de Lavras.

Menezes JM, Silva Junior GC, Prado RB (2013) Índice de Qualidade de Água (WQICCME) Aplicado à Avaliação de Aquíferos do Estado do Rio de Janeiro. Águas

Subterrâneas 27(2):79-92.
Moscuzza C, Volpedo AV, Ojeda C, Fernández Cirelli A (2007) Water quality index as an tool for river assessment in agricultural areas in the pampean plains of Argentina. Journal of Urban and Environmental Engineering 1(1):1825 .

Naveedullah N, Hashmi MZ, Yu C, Shen C, Muhammad N, Shen H, Chen Y (2016) Water Quality Characterization of the Siling Reservoir (Zhejiang, China) Using Water Quality Index. CLEAN-Soil, Air, Water 44(5):553-562.

Oliveira ARM (2017) Desenvolvimento de índices de qualidade da água com número reduzido de parâmetros Tese Doutorado, Universidade Federal de Viçosa.

Pesce SF, Wunderlin DA (2000) Use of water quality indices to verify the impact of Córdoba City (Argentina) on Suquía River. Water Research 34(11):2915-2926.

Sabino CVS, Lage LV, Almeida KCB (2014) Uso de métodos estatísticos robustos na análise ambiental. Engenharia Sanitária e Ambiental 19(spe):87-94. DOI: https://dx.doi.org/10.1590/S1413-41522014019010000588

Sánchez E, Colmenarejo MF, Vicente J, Rubio A, García MG, Travieso L, Borja R (2007) Use of the water quality index and dissolved oxygen deficit as simple indicators of watersheds pollution. Ecological Indicators 7(2):315-328. DOI: https://dx.doi.org/10.1016/j.ecolind.2006.02.005

São Paulo - Secretaria de Saneamento e Recursos Hídricos; Coordenadoria de Recursos Hídricos (2011) Relatório de situação dos recursos hídricos do estado de São Paulo. São Paulo, SSRH/CRHi, 208p.

São Paulo - Secretaria de Saneamento e Recursos Hídricos; Coordenadoria de Recursos Hídricos (2013) Plano estadual de recursos hídricos (PERH): 2012/2015. São Paulo, SSRH/CRHi, 210p.

Srivastava G, Kumar P (2013) Water quality index with missing parameters. International Journal of research in Engineering and Technology 2(4):609-614.

Tyagi S, Sharma B, Singh P, Dobhal R (2013) Water quality assessment in terms of water quality index. American Journal of Water Resources 1(3):34-38. von Sperling, M (2007) Estudos e modelagem da qualidade da água de rios. Belo Horizonte, Editora UFMG, $588 \mathrm{p}$.

von Sperling, M (2014) Introdução à qualidade das águas e ao tratamento de esgotos. Belo Horizonte, Editora UFMG, 4 ed. 452 p. 